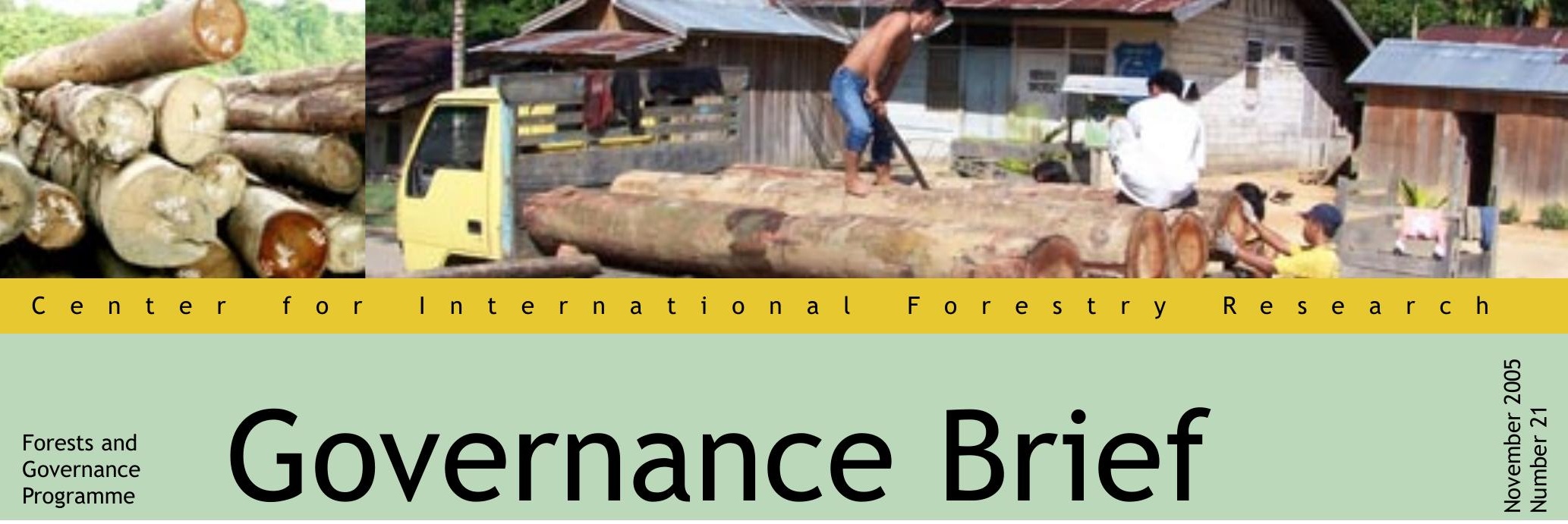

\title{
International Cooperation Against Financial Backers of Illegal Logging
}

\author{
Bambang Setiono \\ Policy and Financial Analyst, Center for International Forestry Research (CIFOR)
}

\section{International Finance and Timber Trading}

International financial institutions have taken part in financing timber extraction in Indonesia. They included Credit Suissee First Boston, ING Bank N.V., and Credit Lyonnais of Singapore (Setiono, 2005). By 1999 four Dutch banks; ABN-AMRO Bank, ING Bank, Rabobank, and Mees Pierson, had invested in 740,000 ha of oil palm plantations in Indonesia (Wakker, 2000). Since the early 1990s, international financial institutions have played a critical role in facilitating the rapid expansion of the Indonesian pulp and paper industries. They were responsible for channeling over US\$12 billion into these industries by 1999 (Barr, 2001).

International financial institutions serving Malaysian and Singaporean timber trading companies should be aware of risks involving illegal timber trading. Many reports have suggested the involvement of businessmen or financial backers from Malaysia and Singapore in illegal logging activities in Indonesia. The dominant role of Malaysian financial backers in illegal logging activities is apparent in Indonesia's West Kalimantan province. There are three gateways for illegal Indonesian logs to enter Sarawak Malaysia; these are the harbors of Entikong, Badau, and Sematan. In 2002, $354,816 \mathrm{~m} 3$ of illegal logs were transported via Entikong, another 360,866 m3 passed through Badau, while a further 372,168 m3 passed through Sematan Harbor (Budiarto, 2003) and (Alqadrie et al, 2002).

\section{International Capacity to Curb Illegal Logging}

Fighting forestry crime, particularly illegal logging, has become a growing international concern over the past five years. ${ }^{1}$ Several initiatives have been introduced to develop international cooperation against forestry crime. These include the Forest, Law Enforcement, and Governance (FLEG) initiatives in Asia and Africa, the Asia Forest Partnership (AFP) sponsored by the Japanese and Indonesian governments, the European Commission Action Plan on FLEGT and the proposed FLEG in Latin America.

International cooperation against forestry crime should benefit from international collaboration against money laundering. In the 1989 G-7 Summit in Paris, the Financial Action Task Force ((FATF) on money laundering was created to guide and promote national and international policies for combating money laundering and preventing the financing of terrorism. The FATF is a multidisciplinary body, which meets several times a year bringing together the policy-making power of legal, financial, and law enforcement experts.

Some international initiatives have been introduced recently for using the anti-money laundering regime to stop forestry crime. The European Union has led the initiative in Europe to criminalize illegal logging so that its proceeds can be subject to money laundering legislation (Marijnissen, 2003). In a more promising initiative, in its 2004 typology workshop in Brunei Darussalam, the Asia/Pacific Group (APG) on money laundering agreed to form a working group on illegal logging 


\section{The Basel Committee on Banking Supervision}

In support of the FATF, the Basel Committee on Banking Supervision should issue a special recommendation on prudential requirements relating to high-risk sectors such as the forestry sector and the public sector in developing countries where corrupt practices arewidespread. One key policy on the prudential requirements is the implementation of the 'Know Your Customer' (KYC) principles. The Basel Committee should request bank supervisors to monitor banks' implementation of KYC principles for forestry related transactions. Many major international and local banks are financing pulp and paper industries as well as timber industries.

The Basel Committee, through the Core Principles Liaison Group including the International Monetary Fund (IMF) and the World Bank, could enforce its recommendation through assessment of the implementation of the Core Principles of Banking Supervision by bank supervisors across the world. The Core Principles were developed to provide the international financial community with a benchmark against which the effectiveness of bank supervisory regimes could be assessed. The need for strengthening supervision of banks is being stressed as a major priority since it is now widely recognized that weaknesses in banking systems have been at the core of financial crises in many countries over the past decade (Basel 1999).

The IMF and the World Bank could play an active role in the implementation of the Core Principles. The IMF could influence its member countries to comply with a special recommendation of highrisk sectors in the context of its surveillance mandate. The World Bank too could encourage its clients to adopt a special recommendation on high-risk sectors in the course of its regular operations.

\section{Challenges and Recommendations}

Given the extensive international news coverage on illegal logging and comprehensive international cooperation to combat money laundering crimes in the region, one would expect banks to have begun reporting suspicious financial transactions involving their forestry related customers in Indonesia, Singapore, and Malaysia. Deviations in the normal transaction patterns of customers, and media and NGO reports should have made banks aware of the illegal forestry activities of their customers. However, at the time of writing, only two reports have been submitted to the Indonesian

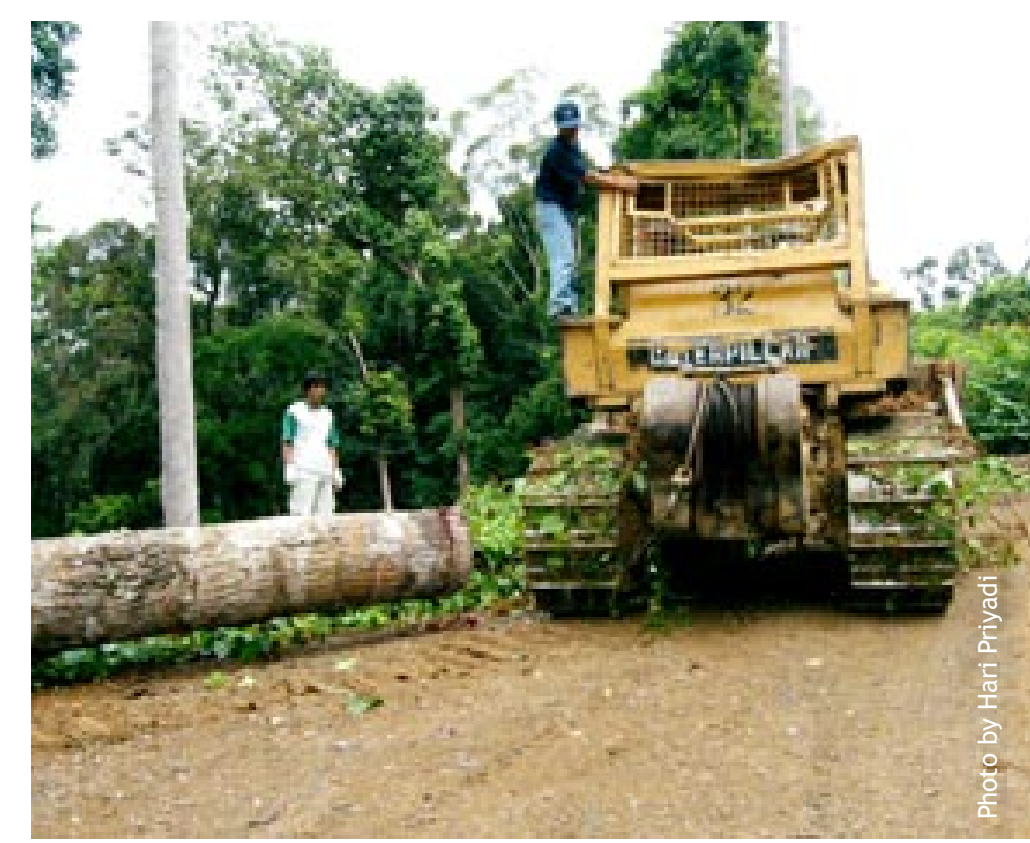

Reporting and Financial Transaction Analysis Centre (PPATK) relating to suspicious financial transactions in the forestry sector. One possible reason for this anomaly is the fact that banks regard most forestry related customers as prime customers because they bring significant business and profits to the banks. The Indonesian timber industry is an important player in the economy with export earnings totaling more than US\$6 billion annually.

International cooperation against illegal logging should now shift to international collaboration against the financial backers of illegal logging and other forestry crimes. The international money-laundering regime could help freeze the accounts of financial backers of illegal logging wherever they keep their accounts in the international financial system, something that could never be achieved using forestry legislation alone.

Policy Recommendations:

1. The Basel Committee on Banking Supervision should issue a special recommendation on prudent requirements and KYC principles relating to the financial backers of illegal logging and other forestry crimes.

2. The Basel Committee should encourage banking supervisors in Japan, China, Singapore, Malaysia, USA, and Europe to audit the implementation of KYC principles and the AML law by banks that are significantly involved in the plywood, sawn timber, pulp and paper, oil palm, and mining industries. 
3. At this stage, international cooperation to use anti money laundering laws for fighting forestry crime has just begun. It is encouraging that the Asia Pacific Group (APG) on money laundering considers illegal logging to be as serious an offence as drug trafficking or terrorism. In collaboration with international initiatives against forestry crimes such as FLEGT, the FATF should support the APG in creating working groups to study illegal logging and in developing measures to combat it. The FATF should also issue a special recommendation or policy regarding forestry and environmental crime.

\section{Reference}

Alqadrie, Ibrahim Syarif, Ngusmanto, Tri Budiarto, Erdi, 2002, Decentralization policies in the forestry sector and their impacts on sustainable forests and local livelihoods in Kapuas Hulu District, West Kalimantan, CIFOR and Tanjung Pura University.

Barr, Christopher, 2001, Bankingon Sustainability: Structural Adjustment and Forestry Reform in Post-Suharto Indonesia, WWF Macroeconomics for Sustainable Development Program Office and Center for International Forestry Research Publication
Budiarto, Tri, 2003, Case Study on Illegal logging, livelihood security and conflict: the case study of West Kalimantan, Adelphi Research, August.

Patlis, M. Jason, (2003), Holding the Purse Strings to Illegal Forestry Activities: Engagement with Financial Institutions and Investigation of Financial Crimes, April, CIFOR

Setiono, Bambang, 2005, Debt Settlement of Indonesian Forestry Conglomerates, CIFOR Forest \& Governance Working Paper. CIFOR, Bogor, Indonesia.

Wakker, Eric, Gelder, W. Jan, and Telapak Sawit Team, 2000, Funding Forest Destruction, the Involvement of Dutch Banks in the Financing of Oil Palm Plantations in Indonesia, a Report for Greenpeace Netherlands.

\section{Footnotes}

1 See details on the history of growing international concern over forestry crimes in the International Forestry Review Vol. 5 (3), September 2003, Special Issues: Illegal Logging.

2 FATF Recommendation No. 26

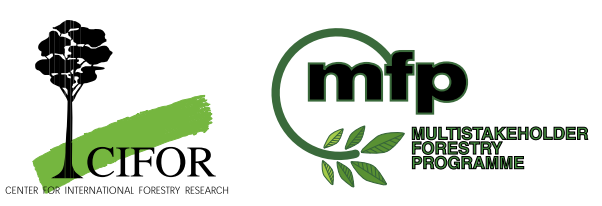

Center for International Forestry Research, CIFOR Office: Jalan CIFOR, Situ Gede, Sindang Barang, Bogor Barat 16680, Indonesia.

Mailing: P.O. Box. 6596 JKPWB, Jakarta 10065, Indonesia
Tel: +62(251) 622622 Fax: +62(251) 622100

E-mail: cifor@cgiar.org Website: www.cifor.cgiar.org Front page photos: Petrus Gunarso and Carol J.P. Colfer 